preparation and constitution of these sensitisers, and tho outbrenk of hostilities found us deprived of sources for these essential materinls.

An investigation carried out by Dr. Mills and myself put us in possession of methods of manufacture and of details concerning the constitution of both Pinnverdol and Pinacyanol, and the wholo of the supplies of these two compounds required by the photographic air services of tho Allies throughout the war were produced (as Sensitol Green and Sensitol Red) in the chemical laboratory of the University of Cnmbridge.

The production of theso substances in this country and the familin rity gaiued by our techuical chemists in dealing with them resulted in very substantial progress being made in panchromatic photography. The best commercial panchromatic plates proviously available required nbout threo times the exposure for red as for blue light, but those now available require less exposure for red than for blue. In consequence of this progress panchromatic plates wero produced which could bo used in air photography with an exposure through a spectroscopically pure red screen of only 0.01 of a second. This fact is of grent importance in war aerin) photography, but it will certninly become of far grenter vnlue now that aerial photography is becoming essential in surveying and topography.

\section{RAIL CONVEYANCE OF CHEMICAL COMMODITIES. (ANOTHER POINT OF VIEW.)}

\section{ARCHBU'T.}

In a recent issue of this Journal, (Sept. 30, p. $315 \mathrm{~N})$ Mr. J. Lukes has discussed the increased railway rates and charges ns they alfect the chemical trade. Ho tells us that from his point of view the chemienl trado has heen very unfairly trented, and for this he lays the blame at the door of the railway companies. Ho charges tho railway companies first, with having regarded practically al "Cliemicals" as "Dangerous Goods," and then with having taken advantngo of their statutory powers to chnrge for theso goods rates which aro oxcessiro, " unreasonable," and oren "onerous"; he even suggests that the Germans outstripped us in the chemical industry beforo the war because of the restrictions plnced by the railway companies on tho movement of chemicals in this country. It will perhaps bo of interest if sono of Mr. Isukes charges are examined in detail.

Are the Thates on Chemicals Unrcasonable? - The statutory maximum rates on non-dnngerous goods. which include many staple products of the chemien industry, wore fixed by parliament in $1891 / 1892$. Some of these rates hare since been reduced by the railway companies, and largo numbers of special low rntes have been given na tho result of represontations made to tho railway companies by the chemical trade.

Leyal Conditions and Rates for Dangerous Goods. - Section 105 of the Railway Clauses Consolidation Act, 1845, to which MIr. Iukes refers, wis enacted in the common interest, and the railwny companies may rofuse to carry goods which in their judgmont are dangerous; but tho companies havo nover abusod their rights under this section, nnd do in fact carry large qunntities of dangerous goods.

It is a soro point with Mr. Inkes that tho decision as to what goods are dangerous under tho condition of railway trnnsit should rest with the railway companies. Would any other arrnngement bo just or reasonablo, seeing that the railway companies are responsible for the safoty of the public, of their stalfs and of the property entrusted to them? It must be admitted that the companies with their vast experience of goods in transit really are the only qualified nuthority on the subject.

The companieg are, howerer, bound by law to exercise their judgment bona fide, and in the only three test cases leard before the Railway and Cannl Commissioners in which the writer wns interested, in two of which Mr. Isukes also was concerned, the Court decided that the railway companies did arrive at their decision in good fnitli and on good grounds. Is not the decision of His Mnjesty's judges sufficient?

Having accepted dangerous goods for conveyance, Part 4 of the Railway Rates and Charges Order Confirmation Acts, $1801 / 1892$, enacts that the charges made for the conveyance must bo reasonable, and the trader has a remedy if he considers the charges excessive.

It is alleged that tho railway companieg have made such use of their opportunities under the Act that they have included "practically all chemical products " within the term "Dangerous Goods." This assertion is wildly incorrect, as a cosunl glance at the Classification will show. The number of chemical products specifically named in the white pages of tho General Railway Classifiention of Goods, i.c., goods carried without special regulations, far exceeds the number listed as dangerous goods, and a closer cxamination will show that the number of chemical products classed as dangerous holds a yet smaller relationship to tho whole, sinco a grent number of chemicals having no dangerous proper. ties and requiring no special regulations as to conditions of carringe are grouped together, without being specifically mentioned, under the generic entry which appears in the white portion of the Classification, viz.:- "Chemicals, not dangeraus, corrosive or explosive. The "Alkali" List and "Packed Iranure" Iist iucludo a large number of staplo products of tho chemical trade which have been carried for many years as ordinary gonils nt exceptionally low rates. It may bo thet Mr. Jukes when spenking of "practieally all chemical products" hnd his horizon limited by benzol, toluol, uaphtha nnd tho like, but the heary chemical in. dinstry is a large and inportant one also.

Mr. Inkes not only charges the railwny com. panies with having gone to the utmost limit of their powers in branding "prnetienlly all chemicals" as dangerous gonds, but ho cites the growth of the Dangerous Goods Section of the General Railway Classifieation of Goods since 1890 as evidence. Now in 1890 there was no Special Classification of Dangerous Goods as it exists to-day. The list of 1890 included $\boldsymbol{n}$ few explosives, a few highly inflammable liquids, and n few chemicals, in no sort of methodical arrangement, and it was full of inconsistencies. To-dny we liave an ordered list, arranged in sections. All Authorised Explosives nre to-rlay carried by railwy and are provided for in the Classification. Inflimmablo Liquids are arranged in two classes, those flashing below and those not flashing holow $73^{\circ} \mathrm{F}$. (close test), Dangerous, Corrosive and Paisonous Chemicals aro divided into tro sections, section 1 including the more dangerous articles, section 2 those less dangerous, and under the heading of Miscellnneous Goods are grouped articles such ns Charconl and Oily Rags, linble to spontnneous ignition, Mntches, Compressed Gnses, otc. The list has grown, nat because the rnilwny companies " havo mado the utmost use of their opportunities," but mainly owing to the inclusion of goods having propertios which have lod to nccidents. Mr. Iukes lays stress upon tho large number of pages in the Dingerous Goods Section, but ho does not strito that of the 212 pages exactly one hinlf is triken up by the Index, By-lnns, Government Orders, Consignment Notes, Specificrtions of 
Packages, etc., that of the remaining half the greater part is taken up by the Packing Conditions, etc., and that the actual number of entries (which includes all Authorised Explosives) is only a small fraction of the total number of the entries in the whole book. He omits to mention that whilst on some pages of the Dangerous Goods Section only one or two articles are mentioned, 30 to 50 articles are to be found on nenrly every white page, and he makes no reference to the fact that Explosives alone account for more than half the total number of entries in the Dangerous Goods Section. In the 1890 list the total number of Explosives was 18 entries on one page, whilst in the list as it appears to-day no fewer than 457 entries appear on 16 pages. The growth of the list is, indeed, to a great extent due to the inventive genius of chemists, which has been especially fruitful in this (Explosives) section of the Dangerous Goods. It must also bo noted that the rates charged for the carriage of dangerous goods have not been generally raised, as Mr. Lukes' remarks would lead one to infer, as a consequence of their transference from the white to the yellow pages; only the conditions aro amended, in order to ensuro safe conveyance. In a great many cases, the transference has been made mainly to inform the railway companies' staffs as to the character of the goods and the precnutions which must be taken in dealing with them to prevent accidents and damage to other goods.

Rates on Jangerous Goods.-As a chemist, I am not able to deal with Mr. Lukes' statements under this hend, but a railway colleague expert in rates, whom 1 have consulted, informs me that MIr. Iukes confuses "Charge" "ith "Class." My friend remarks:- "Certain non-dangerous nerchandiso is included in Class 2 , and the Acts of 1891 and 1892 contain the maximum rates applicable to the traffic in Class 2 divided into chnrges for Conveyance: Station Terminals and Service Terminals. The actual rates on the rate books for trafic in Class 2 (often considerably below the maximum rates) as a rule also include collection and delivery. Petrol in owner's tank wagons is, however, not in Class 2, as Mr. Iukes suggests, and the Genernl Railway Classification snys in respect of it 'Charge Class 2 rate, with the conditions Owner's risk, Station to Station,' which is just a convenient way of namine a rato without incurring the delay inyolved in arranging and issuing an exceptional rate in every case. In effect, there is no difference between charging traflic at a Class 2 rate of $20 \mathrm{~s}$., substituting for its ordinary conditions special conditions, and charging it at an exceptional rate of 203., recorded with those same special conditions.

"Tet us imagine that all Dangerous Goods now charged at Class 2 rates with $\mathrm{S}$. to S., Owner's risk, conditions, were included in Class 2 and subjected to allowances for the services included in the Class Rates but not pęrformed on Dangerous Goods, that would mean a loss of revenue on that traffe. How would that loss be redeemed? It could only be made good by imposing it on other goods; for example, the less Benzol pays the more must Alkali pay, but the henvy branch of the chemieal industry may have some views on the relative claims of their goods to considerntion.

"The same consideratious arise in comnexion with privato sidings, e.g.:-

"A line is opened, stations are built, and the accommodntion is incrensed as the traflic develops, until one dny a firm using one of the stations finds its business has so increased that. it will bo an conomy for it to put down a privnto siding. This is constructed and one-fifth of the tomnag for which the station has been equipped is transferred to the siding; if tho one-fifth is to be rolieved of nny part of the station expenses, tho remaining traffic of the railway must take it if tho revenue is to bo maintained; if the revenus is not maintained, efficiency is at onco crippled."

Decline of the J3ritish, and Growth of the German Coal-tar Colour Industry. -The suggestion that tho British railways erippled the chemical industry in this country and incidentally helped to develop that of Germany is equally incorrect, and will bo assessed at its proper value by members of this Society. The British manufacturers apparently found it better business to export their semi-manufactured chemical commodities to a country where the chomical industry was in such a highly-developed state that the works receiving these commodities could put them through all processes without having to "incur the expenso of a series of movements by rail." Why, therefore, blame the British railways because the trade was so concentrated in Germany that $\mathrm{a}$ "series of movements by rail" was eliminated?

Contract Conditions. -The special contract conditions and indemnity clauses to which Mr. Lukes takes such serious exception npply, as a rulo, in tho caso of explosives and specinlly dangerous traffics, and tho trader only renders himself linble to penalties if he does not comply with the specified conditions as to packing, etc., which tho railway companies consider necessary to ensure safety. It may be, nud no doubt is very largely due to these conditions and regulations that in this country wo have had so few serious accidonts, whilst in America, especially prior to the establishment of the Bureau of Explosives, appalling accidents occurred.

Rolling Stocl:--Under this heading MLr. Lukes mnkes sweeping charges of unrensonable railway rates, but many instances might be quoted of special low rates which havo been given for traffic in Owner's 'Tank Wagons to meet traders' requirements; to mention only two, Crude Naphtha and Fuel Oil, the rates on which aro much lower in tank wagons than in steel barrels. Mr. Lukes does not show that adequate provision has not been made for traflic in privato owner's wagons, tho empty haulage and manipulation of which is a very serious item of expense.

Comparison with Germany and America.-It mny interest Mr. Iukes to know that the serious aceidents which were occurring in America in the transport of Daugerous Goods led to the establishment of the Bureau of Explosives in 1907, and Col. Taylor enme over here on purpose to study our British regulations. Conditions are, of course, very different in the two countries, but ono instance occurs to me in which tho American regulations are more severe than ours. All glass carboys thero have to be boxed and to withstand a swing test. It is very difficult, if not quito impossiblo, to mako a fair comparison between the rates of one country and nnother; tho idenls, tho economics, tho geography and the conditions may bo so entirely different. MIr. Lukes' figures nre much too vaguo to bo of any sorvice as comparisons. To bo of any valuo one requires to know what the various rates include, whether they are fairly represontative, and whether the German rates belong to the preferentinl class or not. It will bo remembered (by many will lasting bitterness) that the Germnn cluemical industry was prostituted, as well as subsidised througl the railways, to further tho grontest schome of world domination ever witnessed.

Mr. Lukes' reference to the recent case in the Railway and Canal Commission Court is quito misleading. Ho snys "it was declared that tho rnilway companies did not accept $150^{\circ} \mathrm{F}$. as the dividing line between danger and snfety, and thoir contention was upheld by tho Court." ATr. Iukes knows that the traflic in disputo flashed at $100^{\circ} \mathrm{F}$. or only a few degrees above this, and his statemont should be compared with the following remarks which wero made by MIr. Justico Lush in dolivering 
his juderment:-" Tho case for the defendants really is that if the flash-point of an oil like this is over $100^{\circ} \mathbf{F}$., which is true of this product, there is no danger in carrying it. Tho railway companies and their advisers and witnesses place the limit of il snfo flash-point at $150^{\circ} \mathrm{l}$. Mlost of these 20 Bamples have a flash-point only slightly over $100^{\circ} \mathrm{F}$., and the highest is $130^{\circ}$. Other authorities seem, from tho documents in evidence before us, to take the same view as to $150^{\circ}$ being the proper line of demarcation. The railway companies aro quito entitled to tako the view which they have taken, that that is tho correct view. That they havo not acted in bad faith in taking it is obviously true."

Dangerous or Non-Dangerous.-Mr. Lukes is very much disturbed becauso the Enclish railway companies are guided by a body of chemists who he says, "generally speaking, have no works' experienco of chemical processes and products; they do not appear to consider whether the merchandise is safo in the package in which it is convoyed, but what might happen in case of a train accident or an accident to a container." Works' experience, which, by the way, many of the chemists havo, is excellent in its place, but is not a primo qualification in connexion with railway transport. Tho frst and foremost qualification in this connexion is experience of commodities in transit and knowledgo of the hazards, both human and mechanical, which are involved. A carboy of corrosive acid may bo relatively harmless when standing in a works whero all the employees know its exact nature, and the proper appliances aro available instantly in caso of accident. It is a very different thing when handed over to the servants of a railway company to bo carried from ono part of tho country to another in company with a thousand other articles. The escape of acid may render all sorts of effects possible, some of them most serious. If the railway companies' advisers did not consider what might happen in the caso of train accidents or the use of leaky containers they would bo quite incompetent to give adrice. Mr. Justico Lush said, referring to the heavy naphtha which was tho subject of the clispute in the Jaw Courts to which Mr. Iukes has referred:- "If securcly packed so that no leakago could possibly tako place tho risk inight, no doubt, be trented as very small. Jut the question is, what the truo claracter of the oil itsel is, not what the danger is if it cannot escapo from the receptaclo that holds it, "and further on in the same judgment ho says "the defendants strongly rely on there having been no accident in tho carriage of these goods when not properly declared, but that is only one element to bo considered. The companies may have been fortunato in not having in accident. The fact that none has occurred does not prove that there was nover any risk. The chief element, or one of tho chief elemente, of danyer which the railway companios repard as serious is this, that if rapour slonuld bo given off, which with the fash-point I have mentioned may well happen, and were to ignite, most serious consequences would follow, and what might have been a small firo, ensily controlled, would rapidly become $n$ serious conflagration through the naphtha coming in contact with other goods on the companies' wagons or premises." Has Mr. I,ukes over henrd of the Abergelo accident in 1868, when tho Jrish mail ran into n goods train carrying lurrels of parafin oil which became ignited and led to 33 persons being burned to death? Such appalling accidents arising from the transport of dangerous groods an 13ritish railwas linvo fortunately been fow in numbor, and this lins largely beon duo to tho companies' vigilanco; but nceidents sorious enough in their why do frequently occur with dancorous roods (the recent contnminntion of Coodstuffs by lenkngo of arsenical weed-killer from a fuulty packngo will bo fresh in mind) and demonstrato thint the manufacturer docs not always appreciato tho dangers of a substanco from a railway transport point of view, although ho may know all about it from his own works' point of view.

Assistance for Key Industry.-MIr. Lukes somplains that no real attention or assistance has been given to the chemical industry so far as carriers uro concerned, but I may remind him that many days have been spent during tho past fow months in classifying dye-intermediates in order to help tho dye industry, and that an endeavour has been mado to fix uniform rates and conditions for as many as possible of these important products. The assistance of "key" industries for State purposes is, however, not the province of a railway company.

Hevision of Ilail way Rates.-Mr. Lukes is anxious that what bo calls an "impartial business tribunal," easy of access and inexpensive, should bo appointed with the power to classify merchandise of overy description, including dangerous goods. If it should be decided to estaûlish yet mother tribunal, I hope that Mr. Iukes will find as much patient attention and consideration given to theso matters, and as much desire to meet the requirements of traders, as has been given during my experience of nearly 30 years by the Chemists' and Dangerous Goods Committees of the Railway Clearing Houso. Our practice has been for a long timo past, whenever serious complaints regarding important matters have como before us, to arrango interviews with the traders concerned, and in most cases wo havo been ablo to fix regulations which have romoved the difficulties.

In concluding this article I havo to thank several of my railway colleagues who havo given mo the benefit of their suggestions. One of them remarks:- " An adequate revenue for railway companies has to be found from somewhero, and it is argely a matter of indifference where it comes from. If the heavy chemical trade is prepared to pay more, it may be that it could be arranged for tho light chemical trade to pay less; also, if the users of stations were prepared to shoulder the wholo of tho terminal costs, siding traffic might bo free of it, but this is certain, that the benzol, toluol and maphthia industry cannot have its charges grently reduced without somebody benring tho burdon they drop, and it will have to bo proved that thoy aro in a rorse position than others, and entitled to greater consideration in consequence, before this is likely to occur."

\section{PROBLEMS AWAITING SOLUTION:}

Tho address which Prof. W. D. Bnncroft delivered, as chairmnn, to the Division of Chemistry and Chemical 'Technology of tho National Resenrch Council (U.S.A.), and which is published in tho Journal of Industrial and Dngineering Chemistry for September (pp. 911-918), contains many suggestive romarks concerning problems of scientific and technological importance which lio within tho borderlands of chemistry and one or more other sciences. Some of theso problems aro briefly outlined beloil :-

It is woll known that, in goneral, flour with moro gluten makes a bettor lonf than flour with less gluten, whilst certain fours with a relatively low gluton-content make quito as good lonves as other flours with larger amounits of gluten. I'o account for this the bakers havo assumed tho existence of strong nnd wenk glutens, but this does not scom consistent with thoir similarity or identity of chemienl composition. Staleness in bread is nppurently duo to $n$ displncement in the distribution of the water-content betweon tho gluten and 